\title{
Marine Scientific Research in South Pacific in the Perspective of Marine Strategy
}

\author{
Jia-rui Liang \\ Liaocheng University, Liaocheng, China
}

\begin{abstract}
As an important marine enterprise, marine scientific research serves to national marine strategy. Since the $21 \mathrm{st}$ century, with the development of international geopolitics, South Pacific in becoming an important sea area, so the marine scientific research in this sea area is becoming hot points. At present, extraterritorial nations including Germany, America, China and UK are conducting marine scientific research in this sea area mainly because of its abundant deep-sea resources, the need to protect marine environment and serving for marine strategic access. With deep-sea's technology improving continually, deep-sea resources in South Pacific will be explored further, marine scientific research cooperation's potential for extraterritorial nations will be great, so more and more nations will involve in conducting marine scientific research in South Pacific. As far as China is concerned, marine scientific research is not only the basis for it to practice marine strategy in South Pacific region, but also the important topic for it to cooperate with extraterritorial nations and pacific islands nations.
\end{abstract}

Keywords: marine scientific research, marine strategy, marine strategic access, South Pacific

\section{Introduction}

As a marine strategy's basis, marine scientific research plays an important role in protecting marine environment, exploring marine resources, knowing the sea area's hydrological data and so on. The South Pacific is very large which includes many small island countries. The island countries' land area is very small except Papua New Guinea, but they have a large sea area and rich deep sea resources. Therefore many sea powers are focusing on these sea area. Because South Pacific is far from traditional hot spot in international politics, there is fewer hydrological data about the sea area. With the increasing improvement of South Pacific's geo-strategy value, knowing the sea area's hydrological data is the prerequisite for extraterritorial nations to practice marine strategy in this region since the 21 st century. Marine scientific research is the best way to know the sea area's hydrological data. At present there is more and more research about South Pacific in the academic circle, among which mostly focus on superpowers game, the relations between pacific island countries and extraterritorial nations, the politics and culture about pacific island countries, but lacks holistic approach about South Pacific. This paper will tease the current situation of marine scientific research in South Pacific and discuss the reason as well as its prospect. This paper will not merely describe the marine scientific research, but put it in the frame of marine strategy, so it will have strategic value which also conforms to extraterritorial nations' strategic purpose of involving in South Pacific.

Jia-rui Liang, Lecturer, Research Center for Pacific Island Countries, Liaocheng University. 


\section{Marine Scientific Research in the Perspective of Marine Strategy}

Marine scientific research means any study or related experimental work designed to increase mankind's knowledge of marine environment (Cafliscb \& Piccard, 1978, p. 849). With the development of marine enterprise, marine scientific research is developing rapidly. Many countries and international regimes conducted a lot of comprehensive surveys and special surveys in the oceans. Marine strategy is an important component for national strategy in geographic space, an extension and elaboration in ocean field, a long-term and comprehensive plan about marine development goals, strategic focus, strategic step and so on. Marine strategy is an overall strategy which covers politics, economy, military, society, culture and so on. Marine scientific research is a sub-strategy which serves to national marine strategy. With marine's increasing improvement in the status of international politics, economy and science, great and complex changes have been taking place in the transaction of international waters. International waters mean the high seas and national sea-bed areas outside the coastal state's jurisdictional sea. The strategic status of international waters lie in its wide space and rich resources which are human's common inherited property (Li, 2014, p. 296).

In Gorshkov's view, marine strategy is the component of national strategy whose intension varies based on national strategy's making but being enslaved to a country's economic and social conditions. Navy, shipping fleet, fishing fleet and scientific research vessel can be regarded as material expressions of national sea force. Because of this, a major feature of Soviet's sea expansion is including everything that a maritime power ought to do. The rapid development of marine research is accompanying maritime enterprise's boom. There were more marine research than Soviet-era which were laying a solid foundation for its maritime scientific research activities (Xiao \& Han, 2016, pp. 132-136). America is actively advocating and participating in international cooperation about marine scientific research. Because America has a strong strength for marine scientific research, especially out of seeking marine hegemony, its marine scientific research has the feature of facing the world ocean and surveying the content widely. Meanwhile, America is conducting all kinds of special survey according to its own need. There was about annual average of 100 research vessels conducting large-scale research activities in the 1970s. America put marine survey's emphasis on deep sea relative to coastal marine survey in the early 1950s, and then on coastal zone survey and continental shelf survey. America had its own strategic considerations at that time. Deep sea accounts for about $80 \%$ of the global ocean and has more important strategic status and practical value. The deep sea's unique position makes for submarine's concealment and missile's launching as well as satellite's flight. Moreover, deep sea is the public area that is not designated and has rich resources, so America has special interest in deep sea's marine scientific research in order to control marine resources (Li \&Yu, 2016, p. 147).

\section{The Motivations of Marine Scientific Research in South Pacific}

With the development of international geopolitics, South Pacific is gradually becoming an important sea area since the 21 st century which has become a hot spot for marine scientific research. At present extraterritorial nations including China, America, UK and Germany are conducting marine scientific research in South Pacific because of rich resources in South Pacific and marine environment's protection and serving for marine strategic access.

International deep sea area means human's unknown and unexplored largest potential strategic resource

base. The strategic importance of international deep sea area has become evident since the 21 st century. The 
rapid development of marine high-tech provoked the boom of marine development and promoted the development of modern marine industry. The deep sea with the depth of about 4000 meters accounted for most of the ocean. Most of the deep sea basin is the international public seabed whose exploit depends on the level of marine technology and equipment. There are rich deep sea resources in South Pacific where is a new territory for marine scientific research.

To date, three main kinds of deep sea mineral deposit types have been identified within the national jurisdiction of several Pacific Island countries. The deep sea mineral deposit types are hydrothermal vents and polymetallic manganese nodules as well as cobalt manganese crusts. Hydrothermal vents are active and inactive volcanic vents on the seafloor which precipitate out concentrated minerals, including copper, iron, zinc, silver and gold. It is also known Seafloor Massive Sulphides (SMS). This is resource under development in Nautilus Mineral's Solwara-1 project in Papua New Guinea. The Pacific Island countries known to have SMS occurrences are Fiji, PNG, the Solomon Islands, Tonga and Vanuatu. Polymetallic manganese nodules often occur at great depths from 4000 to 6000 meters. The nodules can contain a mix of cobalt, copper, iron, lead, manganese, nickel and zinc. These are the kind of resources prospected for in the Clarion Clipper Fracture Zone and they are known to occur in the waters of Cook Islands and Kiribati, and to a lesser extent in Niue and Tuvalu. Cobalt manganese crusts can contain other minerals including precious metals and rare earth elements. They are found in a range of 400-4000 meters of depth and known to occur in Niue, Palau, Samoa and Tuvalu (The World Bank, 2016, p. 15).

Like other small island developing countries, Pacific Island countries have narrow land areas but large ocean areas. They are far away from major markets, often with small population spread across many islands and vast distances, and are at the forefront of climate and its impacts. This makes Pacific Island countries fragile to marine environmental governance, so they must rely on international cooperation to deal with the problem. In this context marine scientific research can help them to collect hydrological data, ocean weather information and so on. South Pacific has its own features compared with other oceans. America and France conducted nuclear tests in this area after WW II which caused great damage to marine ecological environment. America conducted thousands of nuclear tests in South Pacific and it conducted 67 times in Marshall Islands and 23 times in Bikini Atoll. France conducted 210 times nuclear tests from 1960 to 1996 in South Pacific, among which 50 times are atmospheric nuclear test and 160 times are underground nuclear test. France was forced to remove nuclear test site in the Sahara Desert to Moruroa Atoll in South Pacific after Algeria got independence in 1962. France has conducted eight times underground nuclear tests in Moruroa Atoll since then. The nuclear tests that western countries conducted have caused many radioactive and chemical substances from 1950s to 1990s and the nuclear test sites mainly distributed in the northern region of Polynesia and French Polynesia. Some Pacific Island countries were deeply concerned about the military goods wastes left in WW II. Nuclear tests make Marshall Islands not suitable for living forever. There were many military goods wastes left in WW II in South Pacific including 3833 warships and civilian ships. These ships' fuel, oil and other pollutants posed great challenge to the submerged reef and coastal zone in Melanesia and Micronesia. Pacific Island countries realized these issues' seriousness, but they have not ability to monitor pollutants or deal with toxic substances (Mclntyre, 2004, p. 24).

Moreover, marine pollution in South Pacific can't be ignored. South Pacific is very large and marine pollution is serious because of two factors. Firstly, the oil of passing ships sometimes leak. When ships were damaged and leak, although the target is clear when rescued, its pollution will be very serious if ships were 
damaged seriously. January 2013 coral reefs and marine ecosystems in the Milne Bay of the Pacific Island nation Papua New Guinea are at serious risk of long-term environmental damage. The reason is an oil spill from a ship that can't aground on a reef on Kwaiawata Island on Christmas Eve, and authorities' long delay in mobilizing an appropriate response to the accident. The Japanese-owned 136-metre reefer vessel MV Asian Lily, which wasn't carrying any refrigerated cargo at the time, was negotiating Milne Bay-a province compromising 160 islands to the southeast of the Papua New Guinean mainland-en route from New Zealand to the Philippines, when the accident occurred (Wilson, 2013). Secondly, the passing ships dumped rubbish. There are much rich fish resource in South Pacific, so many fishing vessels occurred in this sea each year. Many sailors dumped the rubbish into the sea because of lacking supervision. Except for human factors many floating rubbishes are drifted to South Pacific along with the current each year, especially Indian Ocean Tsunami took many floating rubbishes to South Pacific in 2014.

The third motivation for marine scientific research in South Pacific is strategic value of South Pacific marine strategic access. The safety and unblocking of marine strategic access not only influences a country's increasingly extensive security of overseas economic interest, but also influences national relations, international relations and national strategic status. Therefore, any behavior of marine strategic access is not merely military behavior, but national strategic behavior. Fighting and controlling marine strategic access has been the priority for marine powers to manage and plan the oceans. With the development of international geopolitics, South Pacific is gradually becoming important marine strategic access whose energy pathway value is paid attention to by extraterritorial nations. Struggling for oil and insuring oil security has been the priority of each country's politics, economy and military, while energy transport pathway has more important strategic value whose importance is not inferior to energy storage center. International conflicts are likely to occur in energy transport pathway in the future. Blocking, holding back or compelling energy transport to change flowing direction is more useful to attack energy storage directly. Marine strategic access is the lifeline of world economy and $90 \%$ of trade is finished by marine transport. With the rapid increase of energy demand and energy trade's increasing enlargement worldwide, marine strategic access is becoming the life line of energy. All world great powers' energy security strategies are putting the security of sea lane in important position. One important priority of America's national security strategy has been making use of a variety of means to protect oil and gas transportation pathway. United States Department of Energy listed six world's oil transport throats in 1999 which were Malacca Strait, Suez Canal, Panama Canal, Hormuz Strait, Bosporus Strait and Mandeb Strait. The six oil transport pathways' transportation volume exceeded $40 \%$ of world transportation volume. America has been protecting these marine strategic accesses by strong military power.

From the perspective of geographic position, South Pacific region connects the Pacific and Indian Ocean, holds the Pacific shipping lane from America to Asia and occupies the international shipping line from the Northern Hemisphere to Southern Hemisphere even South Polar, so it has become a strategic place which great powers attach great importance on. Unquestionable, the South Pacific region has become a marine strategic access in new times (Liang, 2016, p. 72). The value of energy transportation can't be ignored in South Pacific marine strategic access. The Pacific traffic mainly includes ocean traffic line and offshore traffic line. The busiest traffic lines are the north route, the middle route, the south route, the route from Japan to Southeast Asia and Australia and the route from Russia to Europe among all the traffic lines. All the traffic lines are in South Pacific except the north route. South Pacific shipping line is the channel of trade contacts between the west coastal countries in North and South America (Jin, 2001, p.157). 
At present, international energy have a new eastward-moving tendency. The Wes Asia and North Africa's situations are in sustaining turmoil, moreover, America and Canada made a breakthrough in developing unconventional energy, so western countries is investing fewer in traditional energy source such as Middle East which will compel China to focus more on maintaining the security of marine strategic access. The emerging countries in Asian-Pacific regions are at the stage of rapid economic development, so they will demand more energy. European countries' energy demand declines sharply because of economic crisis, and the center of international energy consumption is transferring to Asian-Pacific region. The global oil consumption was 4.13 billion tons in 2012, among which Asian-Pacific oil consumption was 1.389 billion tons. The transfer of global energy consumption will also influence geopolitical change. China, India, Japan and other Asian-Pacific countries will consume redundant oil in Middle East and South America. South America can be the new place for Asian-Pacific's energy security in the new global energy map. South America is one of important oil production export area where Venezuela, Brazil and Ecuador have the most oil reserves in this area. Venezuela ranks seventh in the world in terms of proven crude oil reserves. Brazil's proven crude oil reserves rank only second to Venezuela. Ecuador is the third largest oil production country because of its rich oil in Central and South America. According to the energy efficiency indicators by International Energy Agency in 2016, Middle East is still the world's largest oil production area. South America accounts for about $9.4 \%$ of world's total oil production (International Energy Agency, 2016, p. 35). At present, because of shale oil production's increase, America's demand for South America's oil is decreasing, so South America's crude oil is beginning to export to Asia. The crude oil's price is likely to be lower in South America than in Middle East, so China, India and Japan's companies are beginning to purchase the oil actively. China Petroleum Group will purchase crude oil from Columbia and Brazil which amounts to two large ships' carrying capacity. In the past two years, China's crude oil import from Venezuela doubled (Ministry of Commerce of PRC, 2013). However, the energy supply from South America is one thing, the security of South Pacific's marine strategic access is another thing. Energy's stable supply not only includes energy's abundant supply, but also includes energy's transport to consuming site timely and safely. As a part of marine strategy, marine scientific research can be the basis of maintaining the security of marine strategic access in South Pacific.

\section{The Current Situation of Marine Scientific Research in South Pacific}

Extraterritorial nations including Germany, America, China and UK are conducting marine scientific research in South Pacific because of its rich deep resource and protecting marine environment as well as serving marine strategic access. As a marine enterprise in the frame of marine strategy, marine scientific research is these countries' inevitable choice to pursue marine power and the basis to practice marine strategy in South Pacific.

As a traditional colonial power in South Pacific, Germany had important influence in South Pacific region in history. Under the leadership of Bismark, Germany's domination expanded to the area with trade relations in 1884. Germany annexed most trust territories of New Guinea including the north coast of New Guinea and Bismark Archipelago. Germany annexed Marshall Islands again in 1885 and merged Nauru in 1888. Western Samoa became Germany's colony in 1885 (Henderson, 1978, pp. 34-40).

Germany withdrew from South Pacific region after WW I. However, Germany's colonial existence in South Pacific region still has important influence on pacific island countries. The few decades of colonial presence of the German Empire had manifold impacts on the social history of the island's populations, which 
are still visible in the 21 st century in toponyms, in words with German origins, in the basic principles of education or in the continuing social commitment of the churches. Also in the realms of economy and trade there are still significant relations, although the emerging Asian states are nowadays unquestionable of more significance for Pacific Island countries than the former European colonial powers. New links between Germany and the Pacific nations arise from a similar range of interests in global issues, particularly with regard to protecting marine environment and facing climate change (Holtz \& Kowasch, 2016, p. 3). Nowadays Germany has a variety of research vessels including all modern elements and covering all ocean fields. As global resource, ocean space plays an important role in climate change. As human is gradually exploiting the ocean, Germany regards the marine exploration as indispensible component in public interest and makes active contributions. Germany has made significant contributions in modern marine science research field which is regarded as an important power in marine research internationally.

With the increasing improvement of marine science and marine strategy's importance in recent years, each country is regarding the construction of research vessels as important measures for the development of marine strategy and science. At present Germany put three global research vessels into use which are ships of Polarstern, Meteor and Sonne. Germany research vessels arrived in waters is North Atlantic, and then is the Baltic Sea, North Sea and Pacific Ocean. There are 1171 Germany research vessels used in Pacific from 2005 to 2010 (Chen, Liu, \& Hao, 2011, p. 32). Germany research vessels once arrived in South Pacific region during the marine scientific research in Pacific (EUROPA, 2006). The flagship of German research vessel - the RV SONNE sailed South Pacific in 2016. Just before the Easter break in 2016, the ship docked in Wellington for a change of the research crew and loading of large equipment. In the capital, the crew loaded the new marine drilling machine MeBo 200. The large piece of equipment was used for the first time during the 2016 research cruise (German Embassy Wellington, 2016). As far as Germany is concerned, South Pacific is its important marine research area in the future.

America is increasingly dependent on ocean resources for energy, raw materials for construction, and minerals vital to emerging communication and information technologies. Resources of high interest and value are gas hydrates, renewable kinetic energy in offshore winds, tides and currents, deposits for rare earth elements. Therefore, marine scientific research is vital to America. America has done much marine scientific research in pacific since 1839 where most research was done in North Pacific. Since then America paid more attention to Southwest Pacific. Now America is grasping more details about pacific by World Oceanographic Data and National Oceanographic Central Data's collecting foreign data widely. America's government has always been attaching great importance on the development of marine science and technology strategy which maintains the leading position in the world. America's highly developed strength of marine scientific research derives from its high ability of marine science and technology. Nowadays, America has the largest marine scientific research institutions with the highest level in the world. Moreover, America has the most marine scientific research vessels with the most advanced equipment in the world and these vessels' track is spreading all over the world ocean. America conducted marine scientific research in Cook Islands in South Pacific whose research objective is mapping tsunami deposits created by landslide generated tsunami in June 2016. America also conducted marine scientific research in Pacific Panama in February 2017 whose research objective is collecting data from six coral reefs in the Gulf of Chiriqui and Gulf of Panama that will be used to monitor coral abundance, coral calcification and bioerosion in relation to oceanographic variability over the next three years (USGS, 2017). 
The report to the 18th National Congress of the Communist Party of China came up with the strategic task to build China into a maritime power which will provide strong support and broad prospect to develop maritime enterprise rapidly. So China's maritime scientific research is ushering in a new development opportunity. China conducted the global ocean scientific research across the three oceans for the first time. China continued to get marine basic data and research findings which have the great significance on marine economy sustainable development, marine resource development, marine environment protection and so on (Cui \& Song, 2015, p. 92). State Oceanic Administration joined up National Development and Reform Commission, Ministry of Education, Ministry of Science and Technology, Ministry of Finance and Chinese Academy Sciences to build national ocean survey fleet in order to adapt expanding marine interest and safeguarding national marine interest and rights in 2012. This ushered in China's marine enterprise entering a new stage which will lay a solid foundation for practice national marine strategy (State Oceanic Administration, 2016).

As the dominant place to observe and control in the world, Pacific Island country's location has a great significance on China's scientific research in the Southern Hemisphere and strategic planning in the future. China has built good relationships with Pacific Island countries which can establish observation base or intermediate station in a mutual benefit way. This can help China not only greatly lower the cost in fields of spaceflight, navigation, oil gas and exploration, but also develop space technology better. China's marine scientific research in South Pacific has entered a substantial stage. China found seafloor hydrothermal areas in South Pacific during the 22nd maritime scientific research in December 2011 which will help China research the structure and evolution of the crust (Xinhua, 2011). China's deep-sea expedition ship "Zhang Qian" was left for Papua New Guinea and its surrounding waters to conduct marine scientific research on 12 July 2016. China would conduct combined study near the sea of New Britain trench, and take the opportunity of cooperating with local mining companies to finish the assessment of mining activities' influence on deep sea environment (Xinhua, 2016).

As a traditional marine hegemony power, UK made a colonial rob in the beginning of 17th century and became the unmatched marine power in the 19th century. UK conducted the marine scientific research for the first time in the world from 1872-1876 which laid a solid foundation for the development of modern marine science. UK founded Marine Science Coordination Commission in 2008 in order to improve the efficiency of UK's marine research by coordinating UK's marine research and practicing marine strategy. UK issued Law of the Sea in 2009 which provided legal protection for its marine economy and marine research. UK Marine Science Strategy clearly defined marine principles, objectives, research emphasis and so on. UK is one of the few countries with the capability and the proven track record to conduct marine research in all parts of the world's oceans. Through the use of UK's ocean-going research vessels, participation in international satellite remote sensing programs, and the development and application of global computer models, UK scientists have made powerful contributions to international oceanography (Marine Science Coordination Commission, 2010, p. 11). Marine scientific research in South Pacific can't be ignored for UK with high technology of marine science which can maintain marine strategic access in South Pacific effectively. In 2004 British Geological Survey became the coordinators of the European Consortium for Ocean Research Drilling (ECORD) Science Operator consortium that implements mission-specific platform expeditions for ECORD on behalf of the Integrated Ocean Drilling Program (2003-2013) and now the International Ocean Discovery Program (2013-2023). In this programme UK has successfully managed major international drilling projects on the fringing reefs around Tahiti in South Pacific (British Geological Survey, 2004). On 30 August 2016 South 
Pacific-UK marine science collaboration has been further strengthened with the signing of a Memorandum of Understanding between the UK Government's Center for Environment Fisheries and Aquaculture Science and the University of South Pacific. The agreement will explore a range of different partnership opportunities in the field of marine science. This Memorandum of Understanding will formalize the excellent working relations between them that have been developed under the Commonwealth Marine Economies Programme. One of the key goals of this programme is to develop capacity within small islands developing states (Cefas, 2016).

\section{Conclusion}

With the improvement of pacific island countries' importance in international geopolitical structure, the value of South Pacific's marine strategic access is increasingly obvious. Marine scientific research in South Pacific is playing a basic role in maintaining the security of marine strategic access. Pacific island countries are so weak that they have no capacity to conduct marine scientific research in South Pacific and they have to rely on international society. As far as extraterritorial nations are concerned, maintaining the security of marine strategic access is their common interest and they are willing to cooperate with pacific islands countries. Meanwhile, as the amount of land resource is reducing constantly, the attention of many nations to the ocean and the competition for deep-sea resource is becoming serious. With the improvement of marine technology, deep-sea resources of South Pacific will be further explored and the cooperation of marine scientific research will be substantial.

China has confirmed the route of the 21st Century Marine Silk Road and one route is from coastal area to South Pacific. Marine scientific research is not only China's basis to practice marine strategy in South Pacific region, but also the important topic for the cooperation between China and Pacific Island countries. However, China is relatively inexperienced in terms of marine scientific research compared with western countries. Germany, UK and America entered South Pacific region very early, so they have congenital advantages. China should give play to the newcoming advantage that realizes overtaking around the curve by breaking through critical deep-sea technology. Jiaolong's successful dive marks China's deep-sea exploration technology is entering a new stage. China ought to regard Jiaolong as a guide and actively expand other related technology's development and application.

\section{References}

British Geological Survey. (2004). Ocean research drilling. Retrieved from http://www.bgs.ac.uk/research/marine/oceanResearchDrilling.html

Cafliscb, L., \& Piccard, J. (1978). The legal regime of marine scientific research and the Third United Nations Conference on the law of the sea. Netherlands International Law Review, 21(3), 849.

Cefas. (2016). New South Pacific-UK marine science partnership to promote environmental research and collaboration. From http://www.cefas.co.uk/news/new-south-pacific-uk-marine-science-partnership-to-promote-environmental-research-and-colla boration/

Chen, X. E., Liu, Y., \& Hao, H. (2011). Germany's scientific research vessel formation. Qingdao: Ocean University of China.

Cui, F., \& Song, N. E. (2015). Report on the development of ocean society of China. Beijing: Social Sciences Academic.

EUROPA. (2006). EU relations with the Pacific Island-A strategy for a strengthened partnership. Retrieved from http://eur-lex.europa.eu/legal-content/EN/ALL/?uri=CELEX\%3A52006DC0248

German Embassy Wellington. (2016). RV SONNE in New Zealand. From http://www.wellington.diplo.de/Vertretung/wellington/en/04__NZL-GER-Relations/NZ-GER-Science-Relations/NZL-GERWISS_2016/Seite_RV-SONNE-in-NZL__eng.html

Henderson, J. W. (1978). Area handbook for Oceania. Washington D.C.: Superintendent of Documents/DA PAM 550-94. 
Holtz, A., \& Kowasch, M. (2016). A region in transition: Politics and power in the Pacific Island Countries. Saarbruecken: Saarland University Press.

International Energy Agency. (2016). Energy Efficiency Indicators Highlights. Retrieved from http://www.iea.org/publications/freepublications/publication/EnergyEfficiencyIndicatorsHighlights_2016.pdf

Jin, H. P. (2001). World oceans military geography. Beijing: National Defense University Press.

Li, Sh. J. (2014). Ocean strategy of main coastal states, Beijing: Ocean Press.

Li, Sh. J., \& Yu, B. H. (2016). Maritime strategy of the United States. Beijing: Current Press.

Liang, J. R. (2016). The tentative analysis of South Pacific region's marine strategic access's role. Theory Monthly, 12 (5), 72.

Marine Science Coordination Commission. (2010). UK marine science strategy. London: Nobel House.

Mclntyre, M. (2004). Pacific environment outlook. Retrieved from http://www.unep.org/PDF/SIDS/Pacific_EO_final.pdf

Ministry of Commerce of PRC. (2013). Asia is expanding oil Import from South America. Retrieved from http://www.mofcom.gov.cn/article/i/jyjl/j/201311/20131100397218.shtml

State Oceanic Administration. (2016). Wang Hong's report on National Ocean Conference. Retrieved from http://www.soa.gov.cn/xw/hyyw_90/201601/t20160125_49861.html

The World Bank. (2016). Precautionary management of deep sea mining potential in Pacific Island Countries. Retrieved from http://pubdocs.worldbank.org/en/125321460949939983/Pacific-Possible-Deep-Sea-Mining.pdf

USGS. (2017). Research themes: Ocean resources for America's needs. Retrieved from https://marine.usgs.gov/fieldactivities/

Wilson, C. (2013). Pacific island wakes up to threat of oil spills. Retrieved from http://www.ipsnews.net/2013/01/pacific-island-wakes-up-to-threat-of-oil-spills/

Xiao, Zh. H., \& Han, D. T. (2016). Maritime strategy of the Russia. Beijing: Current Press.

Xinhua. (2011). China completed global ocean research. Retrieved from http://news.xinhuanet.com/tech/2011-12/12/c_122407527.htm

Xinhua. (2016). China's deep-sea vehicle Zhangqiang made the first voyage to marine Silk Road. Retrieved From http://news.xinhuanet.com/tech/2016-07/12/c_1119207503.htm 